\title{
Deepening Democracy? Promises and challenges of Chile's Road to a New Constitution
}

\author{
Gabriel L. Negretto ${ }^{1}$ (D)
}

Accepted: 8 October 2021 / Published online: 25 October 2021

(c) T.M.C. Asser Press 2021

\begin{abstract}
As a response to mass mobilizations against the political and social status quo, a multiparty agreement activated a process to replace the constitution in Chile, three decades after the country's transition to democracy. I argue that this process has three features that are not only desirable on normative grounds but also shared by successful episodes of constitutional replacement in democratic regimes: the drafting of the new text in an assembly bound by preexisting rules, inclusive mechanisms of representation and decision making, and direct citizen involvement. These features, in interaction with the popular repudiation of the elite-biased institutions inherited from the Pinochet era, might lead to a new constitutional arrangement that deepens democratization by expanding citizen rights, strengthening executive constraints, and removing restrictions on majority rule. Yet the realization of the full democratic potential of this constitutional change depends on the still uncertain ability of constitution makers to compromise on a text that is not only seen as legitimate among ordinary citizens but also promotes coherent goals, effective institutions, and good governance.
\end{abstract}

Keywords Democratization $\cdot$ Constitutional change $\cdot$ Institutional choice $\cdot$ Chile

\section{Introduction}

As a reaction to mass mobilizations against the political and social status quo, a multiparty agreement activated a process to replace the constitution in Chile, three decades after the country's transition to democracy. The process has captured the imagination of Chileans and external observers because it may work as a peaceful solution to social conflict and dismantle the remnants of a constitution originally designed to restrict popular rule. It also promises a new model of democratic

Gabriel L. Negretto

gabriel.negretto@uc.cl

https://gabrielnegretto.com/

1 Instituto de Ciencia Política, Pontificia Universidad Católica de Chile, Santiago, Chile 
constitution making in a region where citizen dissatisfaction with democratic performance all too often led to polarizing plebiscitarian processes of constitutional replacement that facilitated authoritarian regressions.

I argue that this process has three features that are not only desirable on normative grounds but also shared by successful episodes of constitutional replacement in democratic regimes: the drafting of the new text in an assembly bound by preexisting rules, inclusive mechanisms of representation and decision making, and direct citizen involvement. These features, in interaction with the popular repudiation of the elite-biased institutions inherited from the Pinochet era, might lead to a new constitutional arrangement that deepens democratization by expanding citizen rights, strengthening executive constraints, and removing restrictions on majority rule. Yet the realization of the full democratic potential of this constitutional change depends on the still uncertain ability of constitution makers to compromise on a text that is not only seen as legitimate among ordinary citizens but also promotes coherent goals, effective institutions, and good governance.

The article starts by presenting the main legal and political features of the Chilean constitution-making process. A second section assesses these features in normative and comparative terms. A third section discusses how the interaction between context and process might have an impact on institutional choice. A fourth section examines the main challenges that constitution makers in Chile face to deepening democracy through constitutional change. A final section concludes.

\section{Legal and Political Features of the Chilean Constitution-Making Process}

On November 15, 2019, after a month of massive social protests across the country, representatives of the main political forces in Chile signed on an agreement, called the Agreement for Social Peace and a New Constitution (Acuerdo por la Paz Social y la Nueva Constitución). This document acknowledged the need for a deep institutional change in the country and laid out the basic principles that would structure the process to replace the 1980 constitution. The most salient rules of the Agreement sought to ensure a process characterized by direct citizen participation, inclusive decision making, and legal continuity between the old and the new constitution. These rules reflected a balance between the constraints imposed by popular demands of radical transformation and the desire of traditional political elites to reduce the uncertainty of the process.

The Agreement established that people would vote in a referendum for or against the adoption of a new constitution and the type of constitution-making body responsible for its drafting, that this body would be (fully or partially) elected according to the system to elect legislators, that it would act as a constitutional convention, and that the norms of the new constitution and the rules to approve them would be adopted by a two-thirds majority of the convention. It also proposed that delegates to the convention could not compete for elected positions for a year after the end of their commission, that the convention should complete its work in 9 months (with a possible extension to 12 ), and that a popular referendum with mandatory voting 
would be required for the final enactment of the new text. Finally, it was agreed that the rules for the writing of the new constitution would be included in the existing constitution through a constitutional reform. ${ }^{1}$

In December 2019 a constitutional reform added thirteen new articles to the constitution in force to regulate its own replacement in detail. Apart from ratifying the central guidelines of the Agreement, it regulated the procedure for the initial plebiscite and key aspects of the mandate and decision-making rules of the constitutional convention. After being formally inaugurated, the convention would elect a president and a vice-president by absolute majority and approve the provisions of the new constitution as well as the rules of procedure by two-thirds of the membership. The reform established a mechanism to resolve disputes about its rules of procedure, included details on the possible extension of the convention's mandate, and listed the number of delegates that would be elected per district.

The constitutional reform reinforced one of the core elements of the Agreement, namely the idea that the convention would lack attributes of sovereignty. ${ }^{2}$ This body could not alter its decision rules or procedures for the adoption of agreements, suspend the implementation of the existing constitution while it is in force, take over functions of other branches of government, or alter the terms for which representative institutions were elected, except when they were eliminated or subject to substantial modifications. It also clarified that although the convention would be free to decide on the content of the new Constitution, it must respect the republican nature of the Chilean state, its democratic regime, final and enforceable judicial decisions, and international treaties ratified by Chile that are in force.

Due to the pandemic, the plebiscite was suspended until October 25, 2020. Voters supported the adoption of a new constitution and a fully elected constitutional convention with an overwhelming 78.2 and $79 \%$ of the vote, respectively. According to the provisions of Article 141 of the Constitution, this convention would have 155 members (the same number as the lower chamber of the regular legislature) elected by a D'Hondt proportional formula in 28 districts. Further legal reforms increased the possibility of plural representation in the convention. Independents could compete in each district either sponsored by a party list, as single candidates, or in alliance with other independents in a list. Gender parity was secured by requiring the inclusion of an equal number of men and women as candidates in each list when the number of candidates in the district is even; if it is uneven, there could be only a difference of one in the number of men and women. Similar rules are applied for the distribution of seats. Finally, 17 out of the 155 seats were reserved for indigenous people, also subject to the rule of gender parity.

As we will see, subjecting a democratic constituent process to an ex-ante legal regulation is a frequent phenomenon around the world and Chile (unlike other recent cases in Latin America) is no exception to this trend. Since the idea of replacing

\footnotetext{
1 See Acuerdo por la Paz Social y la Nueva Constitución, at https://obtienearchivo.bcn.cl/obtienearc hivo?id=documentos/10221.1/76280/1/Acuerdo_por_la_Paz.pdf.

2 On the factors leading to the adoption of a new constitution by a special convention in Chile, see Escudero (2021).
} 
Pinochet's constitution gained traction in the country under the center-left government of Michele Bachelet (2013-2017), the most accepted proposal was to channel and limit the process in a legal way. This objective was not only maintained but also reinforced after the process was activated in 2019. In fact, the rules contained in the 13 new articles that the amendment of December 2019 incorporated to the 1980 constitution to structure its own replacement count among the most detailed regulations of this kind. However, those who made the rules could not cover all important aspects of the process or the outcomes that those rules would bring about.

Since his inauguration in 2018, President Sebastían Piñera and his center-right coalition government firmly opposed the idea to replace the 1980 constitution. It was only after massive social mobilizations that expressed a widespread rejection of the status quo that the incumbent government, against its initial preferences, decided to activate a constitution-making process. In spite of acting under constraint, the government was able to demand the two-thirds rule as an essential safeguard to block undesired changes. Yet it was unclear how the rule would work. Would it be applied only for the approval of each provision or also for the final voting of the text as a whole? The left favored the former, while the right the latter interpretation. In either case, what would happen if the threshold was not reached? The political controversy underlying the alternatives explains why the Chilean process is unique in having established a qualified majority rule for the adoption of the new constitution but no deadlock-breaking mechanism in the event of disagreement.

Other important aspects of the process, such as whether the convention would accept the established rules or how it would complete and interpret them, were inherently uncertain because they depended on the outcome of the election of delegates. The veil of ignorance was lifted when this election took place on May 15 and 16,2021 . The election results led to a highly diverse and plural assembly in social, cultural, and political terms, well beyond what could be expected based solely on the rules previously designed to elect delegates to the convention.

The gender parity rule and the reserved seats for indigenous groups secured some results in advance: half of the members of the convention would be women (exactly 77 after the election) and 17 would be from indigenous groups. But other rules simply created the possibility of plural representation without ensuring the result. Such was the case for the election of independents and the way in which proportional rules worked. Compared to the system used to elect Congress, the rules for the election of the convention facilitated the vote for independents; for instance, allowing the vote for independent lists. However, the large proportion of votes for these lists ( $40 \%$ of the total) and the fact that the most voted party list declined from $38.6 \%$ in the last election (2017) to just $20.6 \%$ in the convention election, shows a clear preference by voters for representatives outside parties. Similarly, and relatedly, despite the use of the same proportional electoral formula as in the last legislative election, the level of party fragmentation in the convention significantly increased due to the multiplicity of alternatives and the dispersion of voters' preferences. $^{3}$

\footnotetext{
3 After the election, fragmentation has increased further because factions within some lists have formed separate groups within the convention.
} 
As shown in Table 1, the center-right coalition (Vamos por Chile) was the most voted list and obtained 37 seats, but did not reach the one-third necessary to block decisions. The left coalition (Lista Apruebo Dignidad) outperformed the traditional center-left (Lista del Apruebo) that governed Chile from 1990 to 2010; they obtained 28 and 25 seats, respectively. The most striking result, however, was the success of independents and independent lists, which together obtained 48 seats. The most salient list among them was the Lista del Pueblo, a leftist group linked to various social movements involved in the 2019 protests, which obtained 27 seats, followed by a more centrist list, Independientes no Neutrales, with 11 seats.

Taken as a whole, the results of the convention election reflected a distrust of traditional parties among voters far deeper than initially thought and shifted the position of the median delegate to the left. At the same time, however, the convention election reduced some uncertainties. In the first place, it made the two-third rule, initially widely seen as an imposition of the political right, more universally acceptable. Since no political force or coalition won either a majority to impose or a minority large enough to block decisions, after the election everybody confronted the risk that majorities might emerge to support positions they oppose or that minorities could be organized to reject positions they favor. As we will see, the composition of the convention also made the general orientation of this body more predictable as regards the content of the new constitution.

\section{Normative and Comparative Assessment}

The process described in the previous section has three central characteristics: legal continuity, inclusive representation and decision making, and popular participation. From a normative standpoint, these features are desirable for the design of a new constitution within a preexisting democratic regime. Empirically, they also correlate positively with successful comparative experiences of democratic constitutional replacement.

Subjecting a constitutional replacement to norms of the old constitution is advisable in a democratic regime because it generates predictability and provides institutional safeguards to all the parties involved. It contradicts, however, long-standing views in constitutional theory. The traditional concept of constituent power, for instance, associates the creation of a new constitution with the sudden emergence of the sovereign constituent power of the people, which is the source of all legality and is not bound by pre-existing norms. ${ }^{4}$ This perspective applies relatively well to the adoption of the first democratic constitution that emerges after a disruptive political event, such as the creation of a new state after independence, a revolution, or a regime transition. Yet it is inappropriate to assess the replacement of a constitution within an existing democratic order from a normative standpoint.

The radical distinction between constituted authorities and popular constituent power was born in revolutionary settings due to the inability or unwillingness of

\footnotetext{
${ }^{4}$ See Schmitt (2008), Kalyvas (2005). For an alternative perspective, see Colon-Rios (2020).
} 
Table 1 Constitutional convention. Source: Manual Constitucional 2021, Tres Quintos

\begin{tabular}{|c|c|c|c|}
\hline Representatives by List/Party & Ideology & Seats & $\%$ Seats \\
\hline Vamos por Chile & Center-right/ Right & 37 & 23.87 \\
\hline $\mathrm{RN}$ & & 15 & 9.67 \\
\hline UDI & & 17 & 10.96 \\
\hline EVOPOLI & & 5 & 3.23 \\
\hline REP & & 0 & 0 \\
\hline Lista del apruebo & Center-left & 25 & 16.13 \\
\hline $\mathrm{DC}$ & & 2 & 1.29 \\
\hline PS & & 15 & 9.68 \\
\hline PPD & & 3 & 1.93 \\
\hline PR & & 1 & 0.64 \\
\hline $\mathrm{PL}$ & & 3 & 1.93 \\
\hline PRO & & 1 & 0.64 \\
\hline $\mathrm{CIU}$ & & 0 & 0 \\
\hline Apruebo dignidad & Center-left/ Left & 28 & 18.06 \\
\hline $\mathrm{PC}$ & & 7 & 4.51 \\
\hline $\mathrm{RD}$ & & 9 & 5.80 \\
\hline FRVS & & 4 & 2.58 \\
\hline PI & & 1 & 0.64 \\
\hline $\mathrm{COM}$ & & 1 & 0.64 \\
\hline $\mathrm{CS}$ & & 6 & 3.87 \\
\hline Independientes & & 48 & 30.97 \\
\hline Independientes No Neutrales & Center-left & 11 & 7.09 \\
\hline Lista del Pueblo & Left & 27 & 17.42 \\
\hline Social movements & Mixed & 2 & 1.29 \\
\hline Other independent lists & Mixed & 7 & 4.52 \\
\hline Independents outside lists & NA & 1 & 0.64 \\
\hline Reserved seats & Mixed & 17 & 10.97 \\
\hline Mapuche & & 7 & 4.52 \\
\hline Aimara & & 2 & 1.29 \\
\hline Diaguita & & 1 & 0.64 \\
\hline Quechua & & 1 & 0.64 \\
\hline Lican Antay or Atacameño & & 1 & 0.64 \\
\hline Colla & & 1 & 0.64 \\
\hline Rapa Nui & & 1 & 0.64 \\
\hline Chango & & 1 & 0.64 \\
\hline Kawashkar & & 1 & 0.64 \\
\hline Yagán or Yámana & & 1 & 0.64 \\
\hline TOTAL & & 155 & 100.00 \\
\hline
\end{tabular}


existing institutions to channel the preferences of the majority. This is the reason why the old regime plays a limited or no role in drafting the new constitution in such contexts. In a negotiated transition to democracy, a preexisting parliament may initially participate in the approval of constitutional amendments, but it must be displaced as the constitution-making process moves forward. The situation is different in a democratic regime because existing representative institutions, even if they lost public trust, were freely and fairly elected and must thus have a role in the activation of the process. Courts must also play a role both because popular representatives usually participate in their appointment and because they are regulated by the constitution in force.

For this reason, democratic constitutional replacements fit well into what Arato terms "post-sovereign" constitution making, a process which preserves legal continuity to apply the rule of law to the process itself and prevent arbitrary decisions. ${ }^{5}$ The constitution in force in a democratic regime may itself have a democratic origin and include a procedure for its own replacement, which should then channel the expression of popular preferences for the adoption of a new constitution. Yet even if the existing constitution has an authoritarian origin, it can always be amended to establish the basic procedures of a democratic constitution-making process to build a bridge between the old and the new legality. This was the path taken in Chile when a replacement procedure was incorporated to the 1980 constitution in December 2019. While the convention must adopt its own procedural rules for the drafting, deliberation, and voting of the new text, most structural principles have already been laid out in the constitution.

Legal continuity has several important implications for constitution making. The most important is that the constitution-making body cannot embody any form of sovereign power and must fulfill its mission under the existing constitutional order. This is obvious when the task of writing a new constitution is commissioned to the ordinary legislature acting under special rules. But it should also be the case when a special convention is appointed or elected to write a constitution and function in parallel to the ordinary legislature. Conceptually and historically, these bodies have often successfully claimed to be sovereign and above the constituted bodies, thus inducing institutional conflicts and political instability. ${ }^{6}$ This is the reason why, as we will see, most democracies avoid the use of special conventions as constitutionmaking bodies. ${ }^{7}$

Sometimes, however, when the ordinary legislature has lost public trust as a representative institution, as is usual in contexts of deep crisis of representation, special conventions are the only politically viable constitution-making body. In this situation, legal regulation must grant that the previous constitution be duly observed and that the institutions created under it maintain their full powers until a new

\footnotetext{
5 See Arato (2016).

6 On this point, see Negretto (2018).

7 This is also true under different political conditions. From 1900 to 2015, only 38 out of 124 deliberative bodies created across the world to adopt a new constitution implemented during democratic years can be classified as constituent conventions. See Negretto (2017).
} 
constitution is formally enacted. The designers of the constitution-making process in Chile have gone to great lengths to ensure that the convention would act in this fashion as a non-sovereign constitution-making body.

Inclusive representation and decision making are also normatively desirable principles of constitutional replacement in democratic regimes. Whereas increasing the number of different interests and views represented in the process improves the quality of deliberation before decisions are taken, enlarging the number of actors whose consent is necessary to pass constitutional norms grants that the different interests and views that gain representation are in fact considered in making final decisions. Securing diversity in representation, however, has received wider acceptance in both theory and practice than the consensual approval of constitutions using supermajority rules. There are several reasons for this.

Constituent assemblies, particularly when they take the form of special conventions, tend to make decisions by majority rule, usually absolute majority. ${ }^{8}$ One of the reasons for adopting this rule goes back to the democratic principle of equality. Majority rule treats votes and alternatives equally. Unlike qualified majority, which has a bias toward those who oppose change and gives the status quo a privileged position, majority rule has anonymity (no bias in favor of a particular voter) and neutrality (no bias in favor of a particular alternative) as two central characteristics. ${ }^{9}$ This justification for the use of majority rule is reinforced if one sees elected conventions as embodying the constituent power of the people: every opinion and interest in the convention should count equally, just as when the people express their will in a referendum. ${ }^{10}$

A second, and probably more important reason for the frequent use of majority rule in constitution making is pragmatic. One central feature of majority rule is to be decisive, meaning that it will always produce a decision, at least when the number of voters is even. ${ }^{11}$ By contrast, qualified majority rules are not designed to bring about changes to the status quo, but to prevent those changes when a minority opposes them. For this reason, under qualified majority rule the default option is always the continuity of the status quo. However, new constitutions are usually adopted at times of profound political transformation or crisis, and the decision to initiate a process of replacement implies by itself that maintaining the status quo is no longer an option.

There is an answer to both the normative and pragmatic objections to the use of qualified majority rule in constitutional replacements. On normative grounds, since constitutional norms regulate fundamental rights and liberties as well as access to and the exercise of state power, increasing the number of those who agree to these norms and reducing the number of those dissatisfied with the new constitution is key to enhancing its legitimacy and authority. It is intuitive that the number of those

\footnotetext{
${ }^{8}$ Only 33 of 124 constitution-making bodies created in the world between 1900 and 2015 to adopt a constitution implemented in democratic years required a qualified majority to pass the constitution. Of these, 7 correspond to constituent conventions and 26 to constituent legislatures. See Negretto, ibid.

9 See Schwartzberg (2013).

10 On this point, see Preuss (2008), pp. 217-218.

11 See Novak and Elster (2014), p. 3.
} 
who agree to a decision should be proportional to the importance of the decision, to avoid or reduce negative externalities. As Rousseau famously argued in The Social Contract, "The more important and crucial the decision is, the more nearly unanimous should be the opinion which prevails." 12 This is the reason why unanimous consent or something approaching it occupied an important place in the contractualist tradition to explain the origin of the first contract.The same argument applies when a constitution is established or replaced. ${ }^{13}$

From a pragmatic point of view, although it is true that qualified majority often implies the possibility of rejecting change and maintaining the status quo, this need not be necessarily the case. A wide variety of deadlock-breaking mechanisms could be and often are adopted to produce a decision if disagreement prevents reaching the threshold of votes required for approval. One common provision in his regard, included in the constitution-making processes of South Africa and Tunisia, is to submit the final text to popular approval if reformers fail to reach the required qualified majority. ${ }^{14}$ Similarly, referendums could be used for the approval of disputed provisions rather than the whole text, as in Bolivia. ${ }^{15}$ Also common is the possibility of intervention by expert or political commissions that in the event of disagreement and after some rounds of voting have the capacity to forge a compromise text and submit it to the plenary for approval or rejection (no amendments), for approval with a diminished threshold, or for approval as a default option if a qualified majority is not reached to reject the compromise solution. Some combination of these mechanisms was applied in the constitution-making processes of Kenya, Nepal, and South Africa.

As already discussed, several electoral rules have been established in Chile to secure representative diversity in the convention and after the election of May 2021 this goal has been fulfilled even beyond initial expectations. The two-thirds decision rule, on the other hand, will grant consensual decision making. Shortly after the election, a group of delegates from the left contested the rule but did not find support for changing it for a less demanding threshold. As the implications of not reaching two-thirds of the votes were left undecided, the convention might still complement this rule by creating deadlock-breaking devices in the absence of sufficient consensus for the approval of individual norms (or chapters) or the text as a whole. ${ }^{16}$ Nevertheless, given that no political force or coalition gained enough seats in the assembly to block decisions, that most groups are internally diverse, and that the

\footnotetext{
12 Rousseau (1998), Book IV.

13 Note, however, that the argument does not apply to constitutional amendments, despite the conventional wisdom about the need for qualified majorities to pass them. Requiring qualified majority for amendments produces the opposite effect over time because it deprives new generations of the ability to alter the original constitution. As Schwartzberg argues, by making frequent adjustments more difficult, a qualified majority rule for amendments makes the number of those dissatisfied with the constitution increase over time. See Schwartzberg (2013).

14 See Ebrahim and Miller (2010), Carter Center Report (2014).

15 Bört Irahola (2013).

16 Before this article went to press (October 2021), the convention ratified the two-thirds rule and established that if in a second round of voting the threshold is not reached but a reform is supported by threefifths of the delegates, a referendum could be convened through a constitutional reform.
} 
time limit and the need to secure popular ratification are likely to provide strong incentives to reach agreements, deadlock-breaking devices might be less necessary than they would have been under a different configuration of forces.

Public involvement in the drafting and approval of the constitution is perhaps the most obvious normative requirement for a constitutional replacement in a democratic regime. On the one hand, it is a corollary of the democratic principle that the sovereign people is the holder of constituent power. As Colon Rios points out, regardless of the different forms that the process might take and whether legal limits were established beforehand, direct citizen involvement during the making of a constitution is the irreducible core of the democratic theory of constituent power. ${ }^{17}$ It also underlies our current understanding of democratic legitimacy. Some scholars have even argued that participatory constitution making has evolved into a transnational legal norm. ${ }^{18}$

There is ground for debate, however, about the form that popular participation should take; specifically, whether it should be restricted to voting in referendums. Constitutional referendums, particularly when used to ratify a new constitution, are often considered necessary mechanisms to secure the consent of the governed. Yet they have been criticized for the frequent lack of information that voters may have in the absence of sufficient deliberation on the merits of the proposal. Without deliberation, referendums simply aggregate raw preferences based on ideology or partisanship. ${ }^{19}$ Ideally, the best form of public deliberation is achieved through assemblies made up of randomly selected citizens. ${ }^{20}$ However, whereas these assemblies have existed to propose the essential contents of a new constitution (Iceland) or specific amendments (Ireland), they are still rare. For this reason, the most frequently used mechanisms of citizen participation that do not depend on voting and may promote popular deliberation either directly or indirectly are public forums, hearings, and the submission of citizen reform proposals or comments on drafts.

The main instances of direct popular participation included in the Chilean process were two referendums, one to approve the replacement of the 1980 constitution and the nature of the constitution-making body and another to ratify the text proposed by the convention. It was always assumed, however, that there would also be citizen involvement during the drafting. One of the points of universal agreement among all proposals for rules of procedure presented before the convention was elected was the inclusion of mechanisms of citizen involvement such as public forums, hearings, or proposal submissions by citizens and civil society organizations. ${ }^{21}$ The decline of voter support for traditional parties in the convention has reinforced this preexisting trend and is likely to increase citizen input in the writing of the new text. ${ }^{22}$

\footnotetext{
17 See Colon-Rios (2020).

18 See Hart (2010), Saati (2017).

19 See Tierney (2012), Lenowitz (2015).

20 Fishkin (2011).

21 See Granese (2021). Before this article went to press (October 2021), the convention established several of these participation mechanisms.

22 On the inverse relationship between party strength and citizen participation, see Hudson (2021).
} 


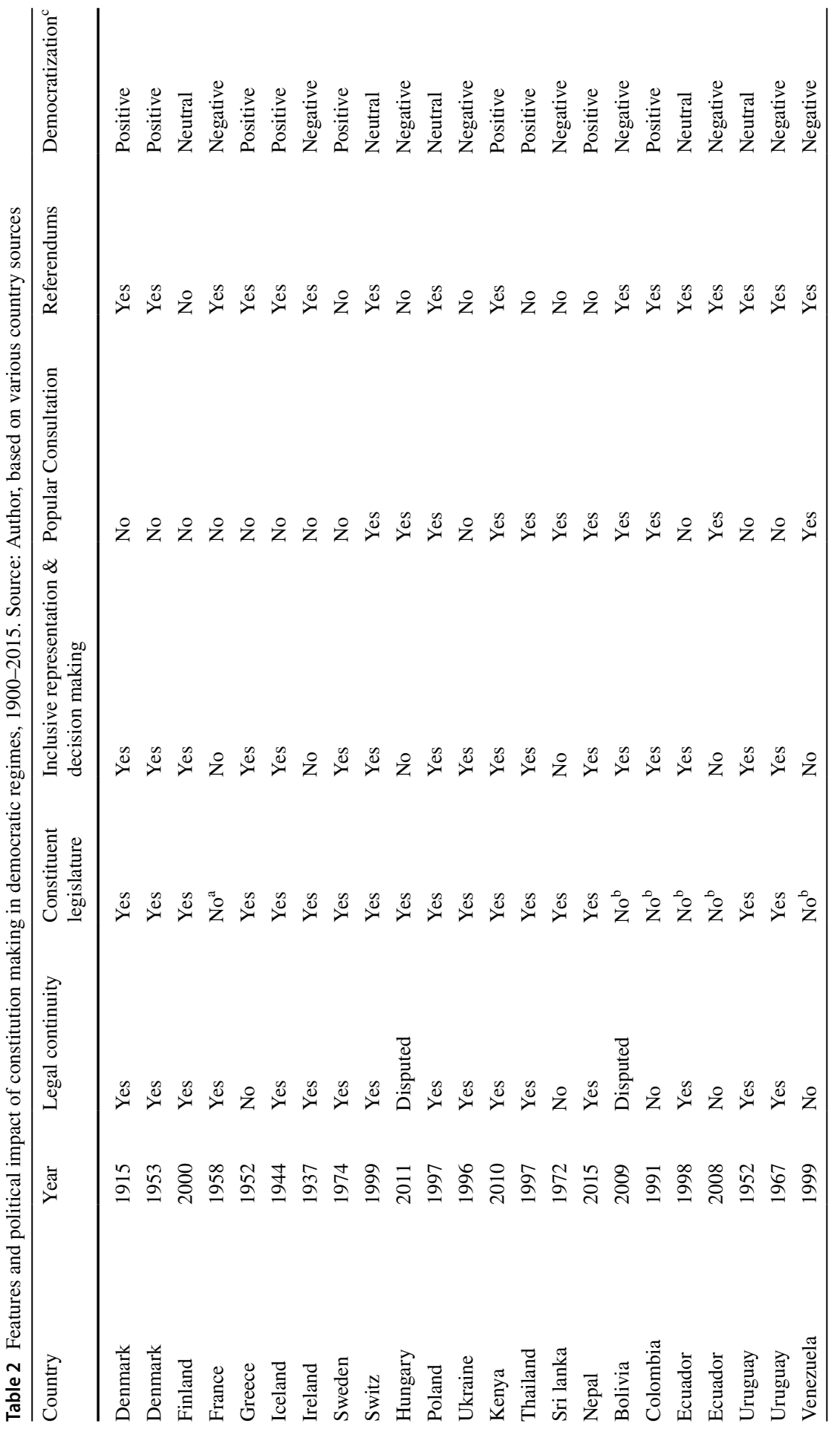




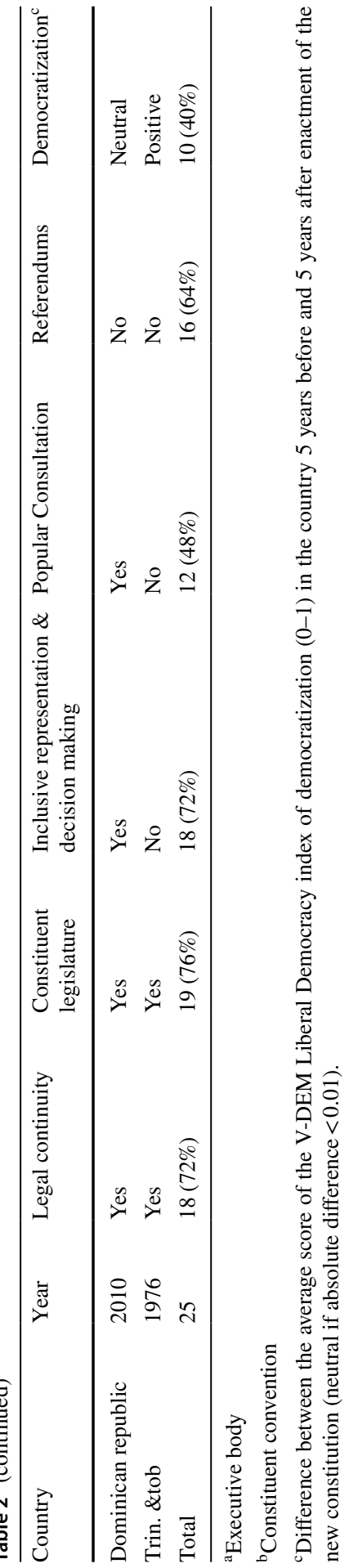


Some of these features are not only advisable from a normative point of view but also correlate with the processes that have been successful in deepening a preexisting democratic regime through constitutional change. Table 2 shows twenty-five new constitutions that have been adopted in independent states where free and fair elections have been held for at least 5 continuous years between 1900 and 2015 . It lists whether legal continuity was observed or contested, whether a legislature (as opposed to an executive body or a special convention) served as the constituent body, whether at least two independent political parties or groups gained representation and had to cooperate to approve the constitution, and whether electoral and nonelectoral forms of popular participation were implemented. The last column shows the short-term political impact of democratic constitutional replacements using the Liberal Democracy Index of the Varieties of Democracy Project (V-DEM), comparing the average scores 5 years before and 5 years after the enactment of the new constitution. $^{23}$

The most visible association is that between legal continuity and inclusive representation and decision making, on the one hand, and positive differential improvements in democratization after the enactment of the new constitution, on the other. In only three of the 16 cases where the level of democratization improved or remained the same after the enactment of the new constitution was legality disrupted or disputed or was the process under the control of a single political force. By contrast, one or both characteristics were associated with 7 of the 9 cases where the level of democratization declined after the new constitution was enacted. Quantitatively, the correlation between the presence of both legality and inclusiveness and a differential improvement in democratization is statistically significant at $\mathrm{p}<0.05$.

Inclusiveness in representation and decision-making is, however, the single most important factor. Large- $\mathrm{N}$ studies using all constitutions enacted in a democratic year (regardless of the age of democracy) have shown that levels of democracy improve after enactment when the new constitution is passed in a plural constitution-making body where at least two political groups were necessary to approve the text. ${ }^{24}$ The reason for this effect is that power dispersion during constitution writing induces the adoption of institutions that protect opposition forces from the arbitrary use of executive power without unduly impairing majority rule, thus enhancing the incentives of the main political actors to abide by the constitution.

Since incumbents may renege on the bargain, the democratizing effect of politically plural constitutional agreements is likely to be short-lived and to last only while the identity of negotiating political forces and the balance of power between them remains stable. ${ }^{25}$ Yet this finding does suggest that electoral and decision-making rules that promote diversity in representation and consensual decision making are important. Table 2 lists cases of inclusive representation and decision making based not on formal rules but on whether in fact a plurality of representatives in the constitution-making body was necessary to approve the constitution. This was

\footnotetext{
${ }^{23}$ Coppedge et al. (2018).

24 See Negretto and Sanchez-Talanquer (2019).

25 Ibid.
} 
strongly determined, however, by the electoral and decision rules of the constitutionmaking body. In fifteen of the eighteen episodes where we observe inclusiveness, a proportional formula was used to elect reformers, a qualified majority rule was required to approve the constitution, or both. Only in Denmark 1915, Thailand 1997, and Ecuador 1998 was cooperation among a plurality of political forces necessary to pass the constitution in the absence of these rules.

By itself, and particularly in the absence of inclusive representation and decision making, direct citizen participation in constitution making does not appear to be associated with democratic improvements. Moreover, as various authors have shown, the use of extensive direct popular participation in processes that are highly exclusionary at the representative level is a typical trait of cases in which constitutional change leads to democratic erosion. ${ }^{26}$ However, citizen participation in different forms is associated with democratization when it follows and complements an inclusive political agreement at the time of enacting a new constitution. ${ }^{27}$ This makes sense when the representative process works well, but the complementarity between inclusiveness at the representative level and participation at the citizen level is probably even more crucial for the deepening of democratization when the linkage between citizens and political representatives has been eroded. This is key for a case like Chile, where constitution making is taking place in the context of a deep and long-standing crisis of representation.

\section{Process, Context, and Institutional Choice}

How a constitution-making process is legally and politically structured; that is, the type of representation and forms of decision in the constitution-making body, the distribution of forces and preferences, and the level of direct popular participation have an influence in the choices reformers make. So do contextual factors such as how the demand for a new constitution relates to preexisting institutions. Insofar as constitutions are replaced when elites or citizens no longer see them as viable governance structures, new constitutions are always more or less reactive to the perceived deficiencies of the preceding constitution. Yet this is a matter of degree. The more the old constitution is seen as a negative model, as seems to be the case in Chile, the more the new constitution will seek to differentiate itself from the previous one. ${ }^{28}$ In what follows, I hypothesize about the content of the new constitution in Chile, considering how features of the process and the reaction against status quo institutions are likely to determine the content of the new text.

\footnotetext{
26 See Partlett (2012), Landau (2013).

27 See Saati (2017).

28 On "negative" constitutions and "aversive" constitutionalism, see Bogdanor (1988) and Scheppele (2003). Prieto and Verdugo characterize Chile's constitution-making process as a dual reaction against both the neoliberal constitutional model inherited from the Pinochet's era and the Bolivarian or populist model associated with recent constitution-making experiences in the Andean region. See Prieto and Verdugo (2021).
} 


\subsection{Expanding Social and Political Rights}

Perhaps the single most clearly predictable outcome about the content of the new constitution in Chile is the expansion of citizen rights, specifically social and political rights. This institutional choice derives both from the level of involvement that citizens will have during the writing and approval of the constitution and from the popular demands that triggered the process precisely to fill in the glaring omissions of the 1980 constitution in this area.

Direct citizen involvement in constitution making has generally been linked to an increase in the number of constitutional rights and the incorporation of participatory institutions in ongoing governance. ${ }^{29}$ Ratification referendums illustrate the mechanism well. This type of referendum creates a 'downstream' constraint on the decisions that reformers can make. ${ }^{30}$ If reformers know or anticipate the preferences of those who have the power to accept or reject their proposals, they have every incentive to satisfy those preferences beforehand. Regardless of whatever else they include in the proposal, the expansion of citizen rights can be presented and is likely to be regarded by the public as an improvement in collective welfare. For this reason, enlarging the list of rights is always a safe strategy to secure popular ratification of the text. This may also apply to the inclusion of mechanisms of citizen participation in the constitution, especially those that were already implemented during the drafting and approval of the new constitution.

The likelihood of this choice increases if one considers the factors that triggered the constitution-making process and the nature of pre-existing institutions in Chile. The massive social mobilizations in October 2019 articulated several important substantive demands: reducing economic inequality, improving pensions and social safety nets, and strengthening the state provision of basic public goods, such as education and health. These demands pre-existed the mobilizations of 2019 and went against the core of the 1980 constitution, which even after a series of reforms during the democratic period still emphasized individual rights and freedoms, restricted state intervention in the regulation of public goods provision, and did not provide judicial protection against state actions or omissions that affected the enjoyment of social rights. ${ }^{31}$ Similarly, this constitution never incorporated mechanisms of direct democracy despite growing popular discontent with political parties and representative institutions.

The proposal for a new constitution made by former president Bachelet already incorporated the right to health and education as justiciable rights and granted the option for a public pension system in addition to the private system created in 1980. It also included mechanisms of direct democracy, such as the right of citizens to propose legislation to Congress. A poll conducted by the newspaper La Tercera among members of the convention on their preferences about the content of the new constitution reveals a high degree of support for the expansion of social rights: more than

\footnotetext{
${ }^{29}$ See Elkins et al. (2008), Ginsburg et al. (2009a, b), Voigt (2004).

${ }^{30}$ See Elster (1995), p. 374.

${ }^{31}$ See Heiss (2020).
} 
two-thirds support creating a universal public health insurance scheme and making water a national resource of public use, and a large majority endorses the state provision of housing and a constitutional guarantee of minimum income. ${ }^{32}$ In addition, more than $75 \%$ of the members of the convention favor including mechanisms of direct citizen participation in the constitution. These preferences are congruent with a process born as a response to social protest against economic and political exclusion.

\subsection{Deepening Representative Diversity and Pluralism}

Just as the need to obtain popular approval for the new constitution may provide members of the convention with an incentive to anticipate the preferences of voters, so reformers may opt for election rules and forms of representation in the new constitution that mirror the composition of the convention itself. ${ }^{33}$ In this regard, the diversity of partisan, gender, ethnic, and regional interests represented at the convention will probably spill over to the political regime at large.

Several studies have shown that the adoption of inclusive and pluralistic electoral rules at times of reform tends to reflect the dispersion of partisan power in the reform body. ${ }^{34}$ This implies that a politically fragmented constituent convention will either maintain or increase the proportionality of the rules to elect representatives in the future legislature, and thus maintain and consolidate a fragmented party system. The decline of parties and the large number of independents in the convention is also likely to strengthen the influence of individual representatives. Independents will be inclined to support electoral reforms that facilitate the election of non-partisan candidates and allow the election of independent lists in future congressional elections. The rule of gender parity, in turn, is likely to be introduced as a norm for the composition of collective bodies, such as future legislatures and high courts. The fact that representatives of indigenous groups account for $11 \%$ of the convention may very well lead to the adoption of reserved seats for indigenous peoples in one or both chambers of Congress.

The decline of parties may also increase the influence of the territorial interests of voters in districts outside Santiago. Since $70 \%$ of the members of the convention were elected in districts outside the metropolitan area of Santiago and many of them were independents, the influence of regional interests is likely to be important in the design of the new constitution; for instance, strengthening the representation of regions in the national government and deepening political and economic decentralization. The 17 delegates from indigenous peoples represent the interests and views of 10 different groups, of which the largest is the Mapuche. It is plausible to assume that these representatives will support reforms strengthening the cultural, legal, and

\footnotetext{
32 Tu Match Constituyente: Los Elegidos, at https://interactivo.latercera.com/tu-match-constituyente-loselegidos/

33 This is a generalization of a hypothesis, initially proposed by Elster (1995), according to which constituent assemblies tend to reproduce their own structure in the new constitution.

34 See Colomer (2004).
} 
political autonomy of their constituents and endorse the declaration of Chile as a plurinational state. Initial preferences among reformers confirm this option. ${ }^{35}$

\subsection{Strengthening Executive Constraints, Lowering Restrictions on Legislative Majorities}

Constitutions emerging out of plural bargains between contending political forces are likely to produce an institutional arrangement that strikes a balance between restrictions on the power of incumbents and majority rule. When no political group has unilateral power to adopt the new constitution and at least some of them expect to alternate in government under competitive conditions, their representatives in the constitution-making body are likely to agree on institutions that constrain executive authority but make it possible for democratically elected governments to govern. ${ }^{36}$ Based on this logic, the Chilean convention is likely to place institutional limits on executive power and reduce restrictions on legislative majorities.

The probability of this choice increases due to several contextual factors. In the first place, the widespread rejection of the institutional legacy of the dictatorship, which in relation to the structure of government was based on an excessively strong president and numerous counter-majoritarian institutions that sought to limit the influence of legislative majorities. ${ }^{37}$ The presidency, along with the Constitutional Court and the Senate, were part of a model of what was termed "protected democracy," whose central goal was to restrict the influence of legislative majorities in the lower house. ${ }^{38}$ The president had strong government and emergency powers and key legislative prerogatives that limited the financial and budgetary powers of the legislature. The Senate, which until 2005 included members of the armed forces selected by the National Security Council, had veto power over legislation. The Constitutional Court, which until 2005 was made up of members appointed by the president; the Supreme Court; the senate; and the National Security Council, had the power to review the constitutionality of laws at the request of both legislative minorities and the executive before they were enacted. This design was completed by various types of laws, such as laws that interpret constitutional provisions and organic constitutional laws that required three-fifths in each chamber and laws of qualified approval (leyes de quorum calificado) that required an absolute majority. ${ }^{39}$

Once Pinochet lost the 1988 plebiscite, some aspects of the original design were altered. For instance, the president lost some powers (such as the power to dissolve congress and the most extreme forms of emergency power) both because they were incompatible with the democratic regime and because they were not necessary now

\footnotetext{
35 See Tu Match Constituyente, footnote 33.

36 See Negretto and Sánchez-Talanquer, footnote 26.

37 See Albertus and Menaldo (2018).

38 See Vergara Estévez (2007).

39 The 1989 amendment lowered the threshold for approval of organic laws from 3/5 to 4/7. I thank Sergio Verdugo for pointing out to me that the original design required 3/5 for both organic laws and laws interpreting the constitution.
} 
that democratic parties would control the presidency. Successive reforms during the democratic period also increased some constraints over the executive or removed some restrictions on majority rule, particularly after the reforms of 2005. Yet the Chilean presidency maintained to this day a set of powers in different dimensions that are among the highest in Latin America and limits on the power of legislative majorities that are unusual not only in the region but also across the world.

An additional factor that may lead to a shift from the inherited allocation of powers between executives and legislatures in Chile is the weak influence of the incumbent president over the process. It is a well-established finding in comparative constitutional analysis that when the incumbent president expects to remain in power after the enactment of the new constitution, the greater his influence over the process (either directly or through his co-partisans in the constituent body) the stronger would be his powers and the weaker would be the powers of other institutions in the future. ${ }^{40}$ This effect has been visible in some recent cases of constitutional replacement in Latin America, such as those in Venezuela (1998-1999) and Ecuador (2007-2008), where the executive and his party had unilateral control over the constituent body; and others, such as the making of the new Bolivian constitution (2006-2009), where the president's party had the largest share of seats. By contrast, in Chile the constitution-making process was imposed on the president rather than promoted by him and he is unable to remain in power after the approval of the new constitution. In addition, there is no clear favorite to win the coming presidential election and even those who rank higher in public opinion lack majority partisan support in the convention. ${ }^{41}$

The interaction between a politically fragmented convention, a legacy of strong presidents and weak legislative majorities associated with the dictatorial past, and the lack of influence of the incumbent executive (or any favorite to win the next presidential election) makes placing more constraints on executive power and reducing restrictions on democratically elected legislators likely. These inclinations are reflected in initial polls among reformers. More than two-thirds of delegates seek to strengthen the legislature vis-à-vis the presidency either by reducing executive prerogatives or by shifting to a mixed regime that divides the executive into a president, who remains as chief of state, and a prime minister, who would fulfill the role of a chief of government accountable to parliament. Also, more than two-thirds of delegates favor either eliminating laws that require qualified majority for approval or reducing the number of areas in which these laws exist. In line with the idea of strengthening legislative majorities, a majority of delegates support eliminating or reducing the powers of the Senate and the Constitutional Court. ${ }^{42}$

\footnotetext{
40 See Negretto (2013).

41 According to a recent poll (September 26 2021), the two main contenders, Gabriel Boric from the center-left and Sebastían Sichel from the center-right, have 23 and $17 \%$ of popular support, respectively. See https://cadem.cl/estudios/plaza-publica-402-kast-se-alza-como-ganador-del-debate-y-alcanza-el-13en-intencion-de-voto-quedando-a-solo-4-puntos-de-sichel-17/

42 See Tu Match Constituyente, footnote 33.
} 
In sum, a constitution that expands citizen rights, deepens representative diversity and pluralism, imposes more restrictions on executive power, and enhances the power of legislative majorities may contribute to improving democracy in Chile. In addition to being drafted with high levels of consensus among representatives and popular participation at the different stages of the process, this design may create incentives among political forces to abide by the constitution and increase its legitimacy and authority in the eyes of citizens. There are several uncertainties, however, as to the details and final form of this design. Constitutions are not simply the sum of isolated provisions but comprehensive and articulated high-order regulations of the political regime. They should work not only as a reservoir of popular aspirations but also as coherent and effective instruments of government. It is unclear whether the new constitution will achieve this goal if reformers to do not strike the right balance between some contradictory demands and avoid some pressures over the process.

\section{The Risk of Ineffective and Inconsistent Institutions}

Despite all the promising attributes of the process, constitution makers in Chile face several challenges. As the process was born in response to social mobilizations and in repudiation of the institutional legacies of the dictatorship, reformers may be tempted to design a constitution that only seeks to translate popular demands into legal provisions and react to the past. In addition, as the drafting of future institutions will take place with full knowledge of the results of elections under the old constitution, reformers may be tempted to select institutions that fit these results too closely. A constitution mainly designed to provide symbolic recognition to popular demands, radically break with previous rules, and serve short-term political interests can result in ineffective and inconsistent institutions that might diminish or impair its positive impact on democracy.

In a democratic regime, elected representatives are supposed to be responsive to popular demands and yet be responsible enough to avoid unfeasible, incoherent, or self-defeating results. ${ }^{43}$ Even when specific reforms are backed by a clear majority of voters, their translation into policies and institutions requires an assessment of priorities and feasibility. The task of representatives, whether they are legislators or constitution makers, is not simply to design policies or institutions to meet popular demands symbolically but to do it in a way in which reforms are effective in improving collective well-being. In addition, as far as majorities are made up of individuals and groups with heterogenous preferences, popular demands may not point to a single reform or may suggest different reforms with potentially opposite results. For this reason, representatives should not only be responsive to popular demands but also make decisions after careful and comprehensive deliberation about the consequences of alternative solutions.

43 On responsiveness and responsibility in democratic regimes, see Pennock (1952). 
The expansion of social rights is an example of a popular reform to which members of the convention should be responsive to strengthen both the legitimacy and authority of the new constitution. Yet this legitimacy and authority is sustainable over time if the new rights effectively improve living conditions for a majority. In general, enshrining rights in a constitution does not automatically grant that those rights will be respected in practice. ${ }^{44}$ In the case of social and economic rights the evidence is particularly mixed and, as the rich experience with social rights in Latin America can attest, there is no clear correlation between the number of social rights listed in the constitution and their effective enforcement on a large scale.This divergence holds even if these rights, as is often the case in the region, are protected by explicit legal actions. ${ }^{45}$ The reason is that the enforcement of economic and social rights on a large scale cannot depend solely on judicial intervention, both because judges tend to rely on individual remedies and negative injunctions and because it leaves unprotected citizens who lack the time or resources to litigate. ${ }^{46}$

While legal principles and actions are important, the actual enjoyment of social rights also demands the establishment of clear obligations for the legislature, the use of administrative capabilities, and the allocation of specific resources. For this reason, constitution makers should make a sober assessment of state capacities and limitations to grant the effectiveness of those social rights that are seen as most important. While some might initial work as guidelines for future state action and judicial interpretation, others might require a more short-term implementation. Simply enlarging the list of new social rights and creating a general regime of strong judicial protection without distinctions may turn out to be ineffective and selfdefeating. A reasonable model of social rights enforcement is one that differentiates between rights, combines explicit obligations and time limits for the legislature and the administration to secure their implementation, and makes judicial intervention a mechanism designed to induce structural solutions by the political branches of government and protect individuals when the existing legislation is violated. ${ }^{47}$

Popular demands, of course, are no guide for design when they are unclear or may be subject to contradictory interpretations. For instance, it is not apparent what the standing of different models of executive-legislative relations is in public opinion. As already argued, the dispersion of power in the convention provides incentives to increase constraints on the executive, and initial polls suggest that most delegates support reform proposals that imply the strengthening of congressional powers. Yet the Chilean Congress is one of the institutions with the lowest level of popular approval in the country and there seems to be weak citizen support to increase its powers. ${ }^{48}$ In this regard, then, being responsive to popular demands either leaves the

\footnotetext{
44 See Chilton and Versteeg (2020) on how the enforcement of rights depends on whether citizens have the collective capacity to mobilize in their defense, which tends to occur only with rights practiced by and within organizations.

45 See Jung et al. (2013).

46 See Landau (2012).

47 For a proposal of a regime of social rights along some of these lines, see Dixon and Verdugo (2021).

48 See https://www.latercera.com/reconstitucion/noticia/encuesta-zoom-de-reconstitucion-43-esta-afavor-de-regimen-donde-la-figura-central-sea-el-presidente-y-no-el-congreso/YZTGD643TVFSHEY D32NFFYYPBI/
} 
decision indeterminate or leads to an inconsistent and potentially risky design such as a mixed regime that retains a powerful president who may conflict with a prime minister accountable to the legislature. ${ }^{49}$

A constitution that is mostly designed in reaction to the past may also lead to suboptimal or inconsistent choices. Although a crucial task of constitution making is overcoming the deficiencies of inherited institutions, constitutions tend to introduce innovations while maintaining some trajectories and making incremental changes. ${ }^{50}$ This facilitates adjustments that build on previous knowledge about the working of existing institutions. The fact that a massive social mobilization against inherited institutions triggered the process of constitutional replacement in Chile and that many members elected to the convention had no or little previous participation in the political system may provide reformers with a strong incentive to engage in a negative design.

As already mentioned, a large percentage of constitution makers seem inclined to eliminate or drastically reform the Senate and the Constitutional Court. This makes sense because these institutions are widely seen as a legacy of the dictatorship. However, too extreme a reaction in the opposite direction might contradict other goals. Creating a unicameral legislature, for instance, goes against the objective of deepening decentralization and securing representative diversity, one of whose dimensions is territorial. Eliminating the Constitutional Court or reducing its powers of judicial review too much, on the other hand, might contradict the need to protect citizen rights and strengthen restrictions on the executive power. Keeping a Senate with territorial representation and weaker powers than the lower house or keeping a Constitutional Court without a priori review of legislation could be more suitable, moderate choices.

The idea of constitutional politics as some sort of elevated human activity, consisting of long-term rationality and aspirations and immune to the short-term partisan interests that characterize ordinary politics, is questionable on both normative and empirical grounds. Constitutional politics is always mixed with ordinary politics. Yet too close an overlap between constitutional drafting and partisan competition may have a negative effect on the institutions selected for the new constitution. The regulation of the convention sought to induce impartiality or at least reduce the influence of electoral interests by preventing members of the convention from competing for representative positions for one year after fulfilling their task. Yet the overlap between elections and constitutional drafting (an unintended consequence of postponing the process due to the outbreak of the COVID-19 pandemic) will provide reformers with strong incentives to base some choices on ideological and partisan interests. This could be another source of inconsistent and suboptimal constitutional design.

As I have shown elsewhere, most new constitutions and amendments in Latin America since 1978 adopted reforms that promote consensual decision-making

49 This conflict is particularly likely in fragmented party system such as the Chilean one.

50 See Elkins et al. (2009). 
along with others that foster concentration of power in the executive branch. ${ }^{51}$ The clearest example is the combination of designs that maintain or increase the legislative powers of presidents while restricting their government powers by means of quasi-parliamentary mechanisms, such as the binding censure vote of cabinet ministers. The influence of short-term political interests and perhaps also the desire to satisfy contradictory popular demands in this area of design might lead Chilean constitution makers to explore a similar blend of institutions with potentially opposite effects.

As the presidential election will take place before the end of 2021, when structural features of the new constitution may not yet be decided, reformers will be designing the executive office with full knowledge of who will be the next president. In this context, while delegates and forces associated with or close to the new president may want to keep a strong presidency, those in opposition may be more inclined to reduce the powers of the office. Since neither group can impose a decision, they would have to reach a compromise. A likely bargain is to keep a relatively powerful presidency in one dimension with reduced powers on another. The results of this hybrid design, however, may also be mixed from the point of view of democratic performance.

\section{Conclusions}

Chile has traditionally been one of the most successful cases of democratization in Latin America. After democracy's reinauguration in 1990, Chile was able to avert problems that plagued other new democracies in the region. Chilean democracy has not been affected by insurmountable political or institutional crises and has had comparatively low levels of public corruption. In addition, after 1990 Chile achieved a well-earned reputation of economic success. Between 1990 and 2010 the country not only increased its per capita annual income more than threefold but also managed to reduce poverty levels from 46 to less than 20 percent. As in most of the region, Chile has experienced relative economic stagnation since 2011. Yet per capita income continued to rise, and poverty recently fell below $10 \%$.

This picture, however, has changed since 2019. Ordinary Chileans took the streets to protest against the cost of living, social and economic inequality, and the underprovision of basic public goods by the state. To placate demands, the government offered the adoption of a new constitution and signed a multiparty agreement to regulate the process. The process has been characterized so far by legality, inclusive mechanisms of representation and decision making, and direct citizen involvement. These features, in interaction with the popular repudiation of an elite-biased democracy, might lead to a new constitutional arrangement that deepens democratization by expanding citizen rights, increasing constraints on executive power, and removing restrictions on majority rule. It also promises a new model of democratic constitution making in a region with few desirable blueprints to follow.

51 Negretto (2013). 
There are, however, some challenges that reformers must overcome to realize the full democratic potential of this constitutional change. Reformers should make decisions that are responsive to popular demands and yet be responsible enough to avoid incoherent and self-defeating results. They should also overcome the deficiencies of inherited institutions while keeping, with adjustments, those that can still work well. In addition, when constitution drafting and elections under the old constitution overlap too closely, as could be the case in Chile, reforms may run the risk of being disruptive or inefficient. A constitution that is simply intended to translate popular demands, react to the past, or fit current electoral results may end up being a suboptimal design for effective democratic governance.

Funding The Fondo Nacional de Desarrollo Científico y Tecnológico (Chile) funded the research for this article through the grant FONDECYT Regular No. 1200060.

\section{References}

Albertus M, Menaldo V (2018) Authoritarianism and the elite origins of democracy. Cambridge University Press, Cambridge

Arato A (2016) Post sovereign constitution making: learning and legitimacy. Oxford University Press, Oxford Banks AM (2008) expanding participation in constitution making: challenges and opportunities. William \& Mary Law Rev 49:1043-1069

Bogdanor V (1988) Introduction. In: Bogdanor V (ed) Constitutions in democratic politics. Gower Publishing, Aldershot, pp 1-13

Bört Irahola C (2013) El Proceso Constituyente Boliviano. In Los Procesos Constituyentes Boliviano y Ecuatoriano: Análisis Comparativo y Prospectiva.

Carter Center Report (2014) The Constitution-Making Process in Tunisia, 2011-2014.

Chilton A, Versteeg M (2020) How constitutional rights matter. Oxford University Press, Oxford

Colomer J (2004) The strategy and history of electoral system choice. In: Colomer J (ed) The handbook of electoral system design. Palgrave, New York, pp 3-78

Colon-Rios J (2012) Constitutionalism: democratic legitimacy and the question of constituent power. Routledge, London

Colon-Rios J (2020) Constitution making through law. In: Negretto G (ed) Redrafting constitutions in democratic regimes: theoretical and comparative perspectives. Cambridge University Press, New York

Coppedge M et al (2018) V-Dem Country-Year Dataset v8. https://www.v-dem.net/en/data/data-version-8/. Accessed March 2019

Dixon R, Verdugo S (2021) Los derechos sociales y la reforma constitucional en Chile: hacia una implementación híbrida, legislativa y judicial. Estud Públ 162:31-73

Ebrahim H, Miller LE (2010) Creating the birth certificate of a new South Africa: Constitution making after apartheid. In: Miller LE (ed) Framing the state in times of transition: case studies in Constitution Making. U.S. Institute of Peace Press, Washington, DC

Elkins Z, Ginsburg T, Blount J (2008) The citizen as founder: public participation in constitutional approval. Temple Law Rev 81(2):361-382

Elkins Z, Ginsburg T, Melton J (2009) The Endurance of National Constitutions. Cambridge: Cambridge University Press. Final Report of the Committee of Experts on Constitutional Review. 2010

Elster J (1995) Forces and mechanisms in constitution-making. Duke Law Rev 45:364-396

Escudero MC (2021) Making a constituent assembly possible in Chile: the shifting costs of opposing change. Bull Lat Am Res, early view online version (July 2021), available at https://onlinelibrary.wiley.com/doi/ 10.1111/blar.13290

Fishkin J (2011) Deliberative Democracy and Constitutions. Soc Philos Policy 28(1):242-260

Gargarella R (2013) (2013) Latin American constitutionalism: 1810-2010. Cambridge University Press, New York

Ginsburg T, Blount J, Elkins Z (2008) The citizen as founder: public participation in constitutional approval. William and Mary Law Rev 81(Summer):360-382 
Ginsburg T, Elkins Z, Blount J (2009a) Does the process of constitution-making matter? Annu Rev Law Soc Science 5(1):20 (223)

Ginsburg T, Elkins Z, Blount J (2009b) Does the process of constitution-making matter? Am Rev Law Soc 5(December):201-223

Granese MM (2021) Propuestas de Reglamento para la Convención: Encuentros y Desencuentros. CEP, Santiago de Chile

Hart V (2010) Constitution making and the right to take part in a public affair. In: Miller LE (ed) Framing the States in times of transition: case studies in constitution making. US Institute of Peace Press, Washington

Heiss C (2020) ¿Por qué necesitamos una nueva constitución? 1987. Aguilar, Santiago de Chile

Hudson A (2021) The veil of participation: citizens and political parties in constitution-making processes. Cambridge University Press, New York

Jung C, Hirschl R, Rosevear E (2013) Economic and social rights in national constitutions. Am J Comp Law 62(4):1043-1098

Kalyvas A (2005) Popular sovereignty, democracy, and the constituent power. Constellations 12(2):223-244

Landau D (2012) The reality of social rights enforcement. Harv Int Law J 53(1):1-81

Landau D (2013) Abusive constitutionalism. UC Davis Law Rev 47:1-58

Lenowitz JA (2015) "A trust that cannot be delegated": the invention of ratification referenda. Am Polit Sci Rev 109(4):803-816

Negretto GL (2013) Making constitutions. Presidents, parties, and institutional choice in Latin America. Cambridge University Press, New York

Negretto GL (2017) Constitution making in comparative perspective. In: Thompson WR (ed) Oxford research encyclopedia of politics. Oxford University Press, Oxford

Negretto GL (2018) Democratic constitution-making bodies: the perils of a partisan convention. Int J Const Law 16(1):254-279

Negretto GL, Sanchez-Talanquer M (2019) Constitutional origins and liberal democracy: a global analysis. Am Polit Sci Rev 115(2):522-536

Novak S, Elster J (2014) Majority decisions: principles and practices. Cambridge University Press, New York

Partlett W (2012) The dangers of popular constitution-making. Brooklyn J Int Law 38(1):193-238

Pennock JR (1952) Responsiveness, responsibility and majority rule. Am Polit Sci Rev 46(3):790-807

Preuss UK (2008) The exercise of constituent power in central and eastern Europe. In: Loughlin M, Walker $\mathrm{N}$ (eds) The paradox of constitutionalism: constituent power and constitutional form. Oxford University Press, New York

Rousseau J-J (1998) The social contract. Penguin, New York

Saati A (2017) Constitution-building bodies and the sequencing of public participation: a comparison of seven empirical cases. J Polit Law 10(3):13-25

Scheppele KL (2003) Aspirational and aversive constitutionalism: the case for studying cross-constitutional influence through negative models. Int J Const Law 1(2):296-324

Schmitt C (2008) Constitutional theory. Duke University Press, Durham

Schwartzberg M (2013) Counting the many: the origins and limits of supermajority rule. Cambridge University Press, New York

Tierney S (2012) Constitutional referendums: the theory and practice of republican deliberation. Oxford University Press, Oxford

Tresquintos (2021) Manual Constitucional Tresquintos 2021-2022

Verdugo S, Prieto M (2021) The dual aversion of Chile's Constitution-making process: Bolivarian constitutionalism and the pinochet constitution. Int J Const Law 19(1):149-168

Vergara Estévez J (2007) La "Democracia Protegida" en Chile. Revi Sociolog 21:45-52

Voigt S (2004) The consequences of popular participation in constitutional choice: towards a comparative analysis. In: van Aaken A, List C, Luetge C (eds) Deliberation and decision: economics, constitutional theory and deliberative democracy. Ashgate, Hants

Publisher's Note Springer Nature remains neutral with regard to jurisdictional claims in published maps and institutional affiliations. 